\title{
Performance and milk quality of cows fed triticale silage or intercropped with oats or
} legumes

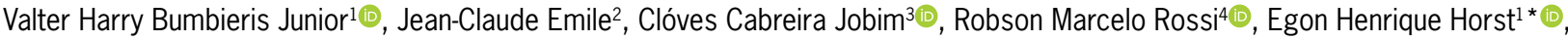 \\ Sandra Novak ${ }^{2}$ (])
}

Universidade Estadual de Londrina/CCA - Depto. de Zootecnia, Rod. Celso Garcia Cid, km 380 - 8605-797 Londrina, PR - Brasil.

2Institut National de la Recherche Agronomique - Le Chêne, Rod. 150 - 80006 - Lusignan, Vienne - France. ${ }^{3}$ Universidade Estadual de Maringá/CCA - Depto. de Zootecnia, Av. Colombo, 5790 - 87020-900 - Maringá, PR - Brasil.

4Universidade Estadual de Maringá/CCE - Depto. de Estatística - Maringá, PR - Brasil.

*Corresponding author <egonhh@yahoo.com.br>

Edited by: Antonio Faciola

Received May 31, 2019

Accepted September 27, 2019
ABSTRACT: The use of intercropped grass legumes provides a source of sustainable animal production as these vegetables contribute to an increase in forage yield by area, and substitute inorganic nitrogen and other components. The objective of this study was to evaluate the nutritional characteristics of silages and the yield and milk quality of Holstein cows fed triticale silages in monoculture or intercropped with either oats or legumes. The crops for silage production were triticale (TS), triticale in consortium with forage pea (TSP), and triticale in consortium with oats, forage peas and vetches (TSOPV). The silages showed no differences in dry matter content. The highest crude protein (13.06 \%) and ethereal extract content was observed in TSOPV, but in the case of the latter, there was little difference when compared with TS (2.35 and $2.16 \%$, respectively) although the ash contents of the TSOPV and TSP silages did present a difference compared to TS silage. The neutral and acid detergent fibers (NDF and ADF) and cellulose fractions of TS silage were higher $(68.60,41.46$ and $38.19 \%$, respectively) than those in TSOPV and TSP silages, which also had higher levels of soluble nitrogen, ethanol and acetic acid. Dry matter intake was higher in both TSOPV and TSP, which also provided a higher milk yield (21.19 and $20.45 \mathrm{~L} \mathrm{cow} \mathrm{d}^{-1}$ ) compared to that of TS silage (18.74 $\mathrm{L} \mathrm{cow} \mathrm{d}^{-1}$ ). Cows fed TS also produced milk with a lower $\mathrm{N}$-ureic content $\left(15.15 \mathrm{mg} \mathrm{dL}^{-1}\right)$. The inclusion of legumes with triticale provided good fermentative quality for silage and increased milk production of cows without altering their concentrations of fat and protein.

Keywords: forage, forage pea, grass, nutritional value, vetch

\section{Introduction}

Seasons marked by little and/or irregular rainfall expose the need for irrigation of fodder crops such as maize which has strong expression for widely known reasons. However, sustainability requires saving these resources, and forces the employment of alternative systems (Emile et al., 2007).

Cereals are considered worldwide one of the main constituents of ruminant feed and are often used as grain in concentrated feed, managed as grazing forage, or used in silage or hay production. Triticale (X. Triticosecale wittmack) has established itself as an alternative forage because of its expressive nutritional results, similar to traditional forage (Bumbieris Junior et al., 2010). In addition, the gains in higher water efficiency and reduced production cost, when compared to sorghum and maize, should be taken into account when choosing crops such as this one (McGoverin et al., 2011).

The use of intercropped grass legumes provides attractive opportunities for sustainable animal production as they contribute to increases in forage yield by area, substitute inorganic nitrogen inputs for the symbiotic fixation of this nutrient, and increase the nutritive value of the forage (Lüscher et al., 2014).

The use of legumes in fodder production systems is an economical method of inserting nitrogen into the system since the legumes, maintained in adequate proportions, offer exceptionally significant potential for fixing this nutrient to the soil (Costa el al., 2012). This fact not only contributes to the maintenance of the competitiveness of livestock production but also corroborates the initiative deployed in sustainable animal production systems (Lüscher et al., 2014).

Believing for the main part, that incorporation of legumes in the triticale can increase protein content and reduce the fiber content of the forage, and that this can evoke positive effects in animal response, we aimed to evaluate the effects of incorporation of forage peas or oats, forage peas and vetches on the triticale culture in terms of the nutritional characteristics of silage together with the yield and milk quality of Holstein cows.

\section{Materials and Methods}

The trial was conducted in Lusignan, Department of Vienne, France, located at the following geographic coordinates $\left(46^{\circ} 25^{\prime} 12^{\prime \prime} \mathrm{N}, 0^{\circ} 07^{\prime} 29^{\prime \prime} \mathrm{E}\right.$, altitude of 150 $\mathrm{m})$. The cultivated area presents soil with a silt texture, an average $\mathrm{pH}$ of 5.8 , and an organic matter content of $3.5 \%$.

The treatments were defined according to the cultures used to produce the silages: TS - triticale (X Triticosecale wittmack); TSP - triticale in consortium with forage pea (Pisum arvense); and TSOPV - triticale in consortium with oats (Avena strigosa Schieb.), forage pea and vetch (Vicia sativa). Triticale and consortia were 
cultivated in an area of approximately 3 ha each using the following cultivars: Grandval ${ }^{\circledR ;}$ Fringante ${ }^{\circledR} ;$ Pepite ${ }^{\circledR}$; and Assas ${ }^{\circledR}$ for triticale, oats, forage pea and vetch, respectively.

For the establishment of triticale in monoculture, 220 seeds $\mathrm{m}^{-2}$ were used. In the consortia, 110 seeds $\mathrm{m}^{-2}$ were used for the grasses, while for the legumes, 20 and 17 seeds $\mathrm{m}^{-2}$ were used for the forage and vetch peas, respectively. The triticale received $80 \mathrm{~kg} \mathrm{ha}^{-1}$ of nitrogen fertilizer in the form of ammonium nitrate in a single application of cover, while the other crops in consortium with legumes did not receive any nitrogen application. All crops were exempted from the application of agrochemicals and other chemical fertilizers as well as from irrigation. Figure 1 shows the temperature and precipitation data during the experimental period of silage utilization.

The cultures were sowed during the transition from autumn to winter and harvested in the spring. For a better understanding, this section was subdivided into two experiments.

\section{Experiment 1: Production and nutritional characteristics of triticale silages in monoculture or intercropped with oats or legumes}

For each treatment, there were eight replicates, each represented by an area of $10 \mathrm{~m}^{2}$. In these experiments, crop yields were assessed at the time of cutting for silage using an automated harvester equipped with a digital balance to record the weight of the forage. A subsample of each replicate was collected to determine dry matter contents. Before the fodder harvest, five samplings of $1 \mathrm{~m}^{2}$ were taken from each area. Species found were manually separated, weighed and then dried to calculate the frequency of each species (Figure 2).

For bromatological analysis and in vitro digestibility of silages, composite samples collected over the last 12 days of each cow feeding period were used to constitute a general sample per period (three) and per treatment. All samples were dried at $55^{\circ} \mathrm{C}$ for $72 \mathrm{~h}$ and then ground in a Wiley mill with a $1 \mathrm{~mm}$ sieve screen.
The dry matter, crude protein, ethereal extract and organic matter contents were estimated according to AOAC (1997). The determination of NDF, ADF, cellulose and lignin were estimated according to Van Soest et al. (1991). The in vitro digestibility of organic matter (IVDOM) of the silages was obtained by the enzymatic method described by Aufrère (1982). The net energy of lactation (NEl) was calculated according to Boever et al. (1999).

Organic acids in the silages was determined according to Erwin et al. (1961), when $10 \mathrm{~mL}$ of liquid extract from the silage was mixed with 2 $\mathrm{mL}$ of metaphosphoric acid. Subsequently, the concentrations of organic acids were determined by gas chromatography on a Shimadzu GC 2010 Chromatograph (Shimadzu Corp.) equipped with an automatic injector, a flame ionization detector and a column TR-FFAP semicapillary of $30 \mathrm{~m} \times 0.53 \mathrm{~mm}$ $\times 1 \mu \mathrm{m}$. To determine the amount of ammoniacal nitrogen, an aliquot of $1 \mathrm{~mL}$ of the liquid extract of silage was added to $5 \mathrm{~mL}$ of a solution of phenol and sodium nitroprusside and $4 \mathrm{~mL}$ of a solution of sodium hypochlorite and sodium hydroxide and plated at 39 ${ }^{\circ} \mathrm{C}$ for $15 \mathrm{~min}$. After this time absorbance was read in a spectrophotometer on a wavelength of $625 \mathrm{~nm}$. Values for $\mathrm{pH}$ were obtained according to Cherney and Cherney (2003), diluting $50 \mathrm{~g}$ of fresh silage in $125 \mathrm{~mL}$ of distilled water, with a readout after $1 \mathrm{~h}$.

The areas used to make silage for animal feed were harvested with a harvester with a rotary disk platform, and stored in a bunker silo, a separate silo being allocated per treatment. Immediately after compacting and loading, the silos were suitably sealed with double-sided tarpaulin.

\section{Experiment 2: Yield and milk quality of Holstein cows fed triticale silages in monoculture or intercropped with oats or legumes \\ After 120 days of storage, the silos were opened} to feed the cows. To evaluate the yield and milk quality, 24 Holstein cows with a mean weight of 600

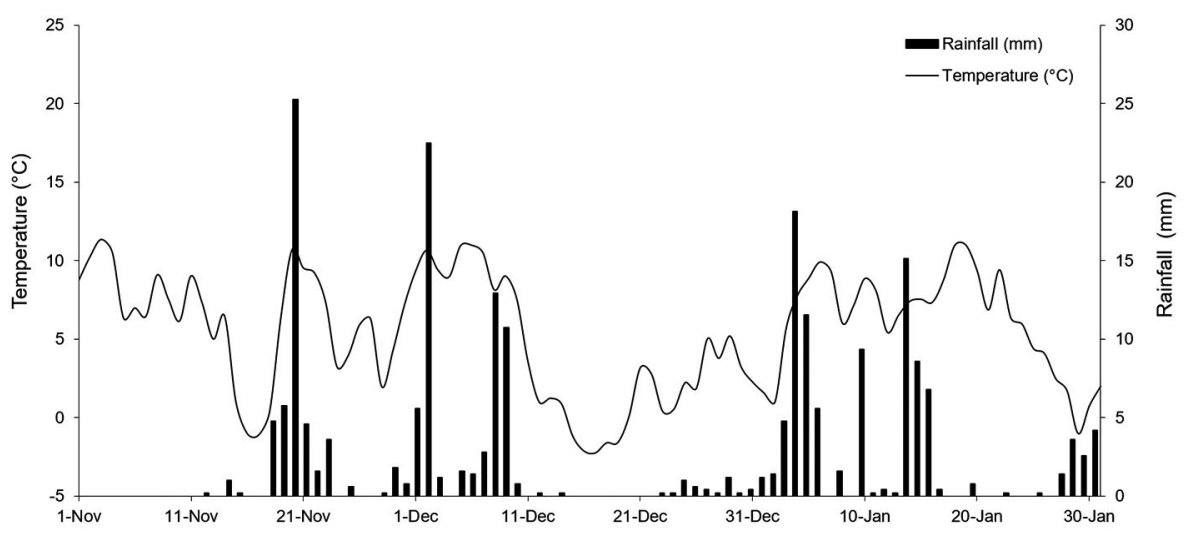

Figure 1 - Temperatures and precipitations during the experimental period. 


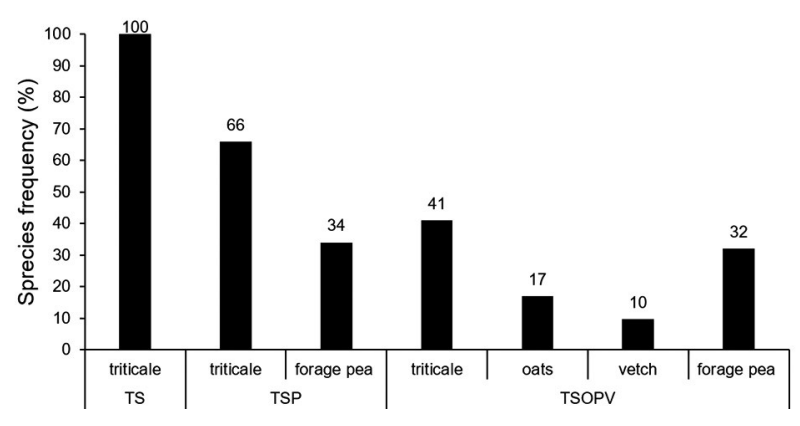

Figure 2 - Frequency of species at harvest time. TS = Triticale silage; TSP = Triticale silage with forage pea; TSOPV = Triticale silage with oats, vetch and forage pea.

$\pm 10 \mathrm{~kg}$ and a mean of $75 \pm 10$ days of lactation were used and separated into three lots of eight animals (three primiparous and five multiparous), taking into account live weight, lactation period and milk production prior to the experiment. The animals were identified with numbered collars and placed in a 3 $\times 3$ Latin square design, with three treatments and three evaluation periods. Animal performance was assessed for 63 days. After a period of 15 days of adaptation, the test was divided into three periods of 21 days each.

A totally mixed diet was provided to complement the diet twice daily with three kilograms of commercially pelleted concentrate. The silage was supplied in the morning only after the cows left post-milking. The concentrate consisted of barley, wheat bran, rape cake, byproducts of amino acid manufacturing, sugar cane molasses, calcium carbonate, sunflower pie, premix of additives and common salt with $18 \%$ crude protein. The animals also received $50 \mathrm{~g}$ of mineral-vitamin complex mixed with the concentrate and had free access to mineral-vitamin complex blocks.

The bays were equipped with automatic drinking troughs with water meters, where data was collected weekly to evaluate the average water consumption per animal lot in each treatment.

Individual milk production was recorded at each milking using volumetric collectors connected to a milking machine under the control of a computerized system. Milk fat and protein contents were obtained by infrared analysis, carried out at Surgères, France from samples collected over four consecutive milkings, always on the $17^{\text {th }}$ and $18^{\text {th }}$ days of each period.

The correction for $4 \%$ milk fat was calculated from the equation described in the NRC (2001). The levels of urea in the milk were obtained using the AZOTEST method, according to Godden et al. (2003).

The animals accessed food via electronic Calan gates (American Calan), with each gate allowing access to a feed box linked to an automatic cow identification system. This system allowed for individual food intake to be recorded.

\section{Statistical analysis}

For dry matter production, bromatological composition and $\mathrm{pH}$ of silages date, we considered that observations of each of $k=1,2,3$ treatments, from a complete randomized design, followed a normal distribution pattern: $y_{i k} \sim N\left(\mu_{k^{i}} \sigma_{k}\right)$, with a the "posteriori" noninformative distributions for hyperparameters $\mu_{k} \sim N\left(0 ; 10^{6}\right)$ and $\sigma_{k} \sim \operatorname{Gama}\left(10^{3}\right.$; $\left.10^{3}\right)$, respectively, for the average and standard deviation according to OpenBugs parameterization $\left(\tau_{k=} 1 / \sigma^{2}\right)$, with the Bayesian program that allows for the determination of "posterior" distributions for the parameters, using the BRugs package in the $\mathrm{R}$ program (R Development Core Team, 2019). For each of the parameters, 30,000 values were generated in an MCMC (Monte Carlo Markov Chain) process, considering a sampling period of 1,000 initial values. The final sample, taken with size five jumps (to eliminate serial autocorrelation), consisted of 6,000 values generated. Chain convergence was verified through the CODA package in the R program, according to the criteria of Heidelberger and Welch (1983). Two-by-two contrasts between the "posteriori" averages distributions due to different treatments, were considered significant if the zero value was within the $95 \%$ credibility range of respective difference.

The experimental design used was a complete randomized design, with three repetitions. Data on dry matter and water intake, yield and milk composition were analyzed using the GLM procedure with averages compared by Tukey's test at $5 \%$ significance using the SAS statistical program (SAS, Inc., Cary, NC).

\section{Results and Discussion}

There was no difference in dry matter content in the silages (Table 1). Although values were considered low for adequate fermentation (McDonald et al., 1991), the presence of legumes did not reduce these values, as was the case of those observed in other studies (Brown et al., 2018). Crude protein contents differed between silages, recording $13.06 \%$ for TSOPV, $11.63 \%$ for TSP and $7.75 \%$ for ST; this can be attributed to the greater inclusion of legumes in the respective mixtures (Figure 2).

Ethereal extract content was higher for TSOPV and TS silages, but the latter did not differ from TSP. Despite the presence of legumes in the mixtures, both vetch and forage pea are considered non-oleaginous legumes, which explains these reduced levels compared to silages with greater grass composition. The ash concentration in the legume silages was higher in relation to the triticale silage in monoculture, probably due to the expressive mineral participation of these legumes. Similar results have been described by Brown et al. (2018). However, Przemysław et al. (2015) evaluated intercropping with alfalfa as the legume crop and reported divergent results.

TS recorded higher levels of NDF, ADF and cellulose than those in the other silages $168.60 \%$, $41.46 \%$ and $38.19 \%$, respectively). These values of 
Table 1 - Mean $( \pm S D$ ) for dry matter production, nutritional value and $\mathrm{pH}$ of triticale silages in monoculture or intercropped with oats and / or legumes, obtained through Bayesian inference.

\begin{tabular}{|c|c|c|c|}
\hline & TS & TSP & TSOPV \\
\hline Dry matter, \% NM & $22.44 \pm 5.02$ & $23.44 \pm 2.76$ & $22.57 \pm 4.19$ \\
\hline Crude protein, \% DM & $7.75^{c} \pm 0.12$ & $11.63^{b} \pm 0.37$ & $13.06^{a} \pm 0.71$ \\
\hline Ethereal extract, \% DM & $2.16^{\mathrm{ab}} \pm 0.41$ & $1.84^{b} \pm 0.12$ & $2.35^{a} \pm 0.14$ \\
\hline Ash, \% DM & $6.11^{\mathrm{b}} \pm 0.21$ & $6.64^{a} \pm 0.30$ & $7.73^{\mathrm{a}} \pm 1.11$ \\
\hline $\mathrm{NDF}, \% \mathrm{DM}$ & $68.60^{\mathrm{a}} \pm 1.33$ & $58.52^{b} \pm 1.87$ & $56.39^{b} \pm 2.86$ \\
\hline$A D F, \%$ DM & $41.46^{\mathrm{a}} \pm 1.67$ & $37.48^{\mathrm{b}} \pm 1.72$ & $36.11^{\mathrm{b}} \pm 2.50$ \\
\hline Cellulose, \% DM & $38.19^{a} \pm 1.38$ & $33.19^{b} \pm 1.63$ & $32.19^{b} \pm 2.05$ \\
\hline Lignin, \% DM & $4.39^{b} \pm 0.55$ & $5.54^{\mathrm{a}} \pm 0.35$ & $5.55^{\mathrm{a}} \pm 1.07$ \\
\hline IVDOM, \% DM & $56.34^{b} \pm 1.22$ & $59.70^{\mathrm{a}} \pm 0.74$ & $60.28^{a} \pm 1.66$ \\
\hline $\mathrm{NEI}$, Mcal Kg of $\mathrm{DM}^{-1}$ & $0.60 \pm 0.07$ & $0.59 \pm 0.06$ & $0.59 \pm 0.07$ \\
\hline Dry matter production, $\mathrm{t}$ of $\mathrm{DM} \mathrm{ha}^{-1}$ & $11.65^{a} \pm 0.81$ & $6.42^{c} \pm 0.31$ & $7.98^{b} \pm 0.35$ \\
\hline $\mathrm{pH}$, índex & $4.04^{\mathrm{ab}} \pm 0.16$ & $3.83^{b} \pm 0.08$ & $4.20^{\mathrm{a}} \pm 0.07$ \\
\hline
\end{tabular}

triticale silage in monoculture are above those reported by Vatandoost et al. (2007) because the triticale cultivar used in the present study is precisely characterized by the self-contained fiber content to be able to support its use in a consortium. The presence of legumes in the intercropping treatments promoted a reduction in the fibrous components of the respective silages.

The use of legumes in consortium increased the lignin contents of TSP and TSOPV silages (5.54 and $5.55 \%)$ due to the high lignification of their stems, while TS presented a value below those mentioned above (4.39\%). According to Costa et al. (2012), grasses present lower concentrations of lignin than legumes, but their lignin apparently inhibits digestion more markedly, probably because grasses have a higher concentration of hemicellulose and lignin which is covalently bound to this fraction.

As noted by Przemysław et al. (2015), the presence of legumes increased the IVDOM of TSP and TSOPV (59.70 and $60.28 \%$, respectively). The difference resulted mainly from the lower contents of fibrous components in these silages, in addition to the higher crude protein contents. In general, legumes have higher digestibility than grasses, which is also true in silage or forage (Dewhurst et al., 2009).

The nutritional advantage of legumes over grasses has been well established. According to Lüscher et al. (2014), caloric concentration, digestibility of organic matter, and the supply of metabolizable protein are generally higher in legumes. These results reflect a lower proportion of structural components of the cell wall, which are less digestible than the cellular content.

Despite the bromatological differences, there was no difference in NEl because the component variables of the prediction equation were different, counterbalancing the minimum and maximum values of each one in the equation. Possibly due to the distinct variables in each equation, Gierus et al. (2012) reported an increase in maintenance net energy for silage with increased legumes and associated the result with the lowest concentration of structural compounds.

In terms of productivity, triticale monoculture silage presented the highest accumulation of dry matter per area (11.65 $\mathrm{t}$ of DM ha $\left.{ }^{-1}\right)$, followed by TSOPV (7.98 $\mathrm{t}$ of DM ha-1) and TSP (6.42 $\mathrm{t}$ of DM ha-1). It is clear that the higher frequency of occurrence of legumes in the area led to a significant reduction in dry matter yield, either due to the characteristic of the species, aggravation or the lack of competition for luminosity, moisture and nutrients. Schmid et al. (2008) reported transgressive overproduction in mixtures rather than monoculture in a few cases, and in these cases, there was a need for approximately five years of establishment to become evident.

TSP presented the lowest $\mathrm{pH}$ value but did not differ significantly from that of TS (3.83 and 4.04). Although dry matter levels were below ideal levels due to early harvesting on account of adverse climatic conditions, the $\mathrm{pH}$ indexes were satisfactory (McDonald et al., 1991) and indicated that there was adequate fermentation. The parameters expressed in absolute values are shown in Table 2.

The absence of legumes in the silage promoted a higher concentration of soluble nitrogen during the fermentation process, which should be a response of the tannins present in TSP and TSPE legumes that bind to protein and reduce its solubility (Dewhurst et al., 2009).

Although the ammonia concentrations of all silages were within the normal range, it seems that the higher frequency of legume appearance in each of the silages caused an increase in ammonia contents, which must be due to the higher protein contents contained in these forages. Costa et al. (2012) suggested that $\mathrm{N}^{-\mathrm{NH}_{3}}$ values for legume silages may range from 10 to $15 \%$, whereas for grass silages, values between 8 and $12 \%$ are acceptable. 
Table 2 - Fermentation quality of triticale silages in monoculture or intercropped with oats and / or legumes, presented in absolute values.

\begin{tabular}{|c|c|c|c|}
\hline & TS & TSP & TSOPV \\
\hline & \multicolumn{3}{|c|}{$\mathrm{N}$ fraction } \\
\hline Soluble nitrogen, \% total $\mathrm{N}$ & 69.10 & 61.10 & 62.80 \\
\hline \multirow[t]{2}{*}{$\mathrm{N}-\mathrm{NH}_{3}, \%$ total $\mathrm{N}$} & 9.73 & 11.40 & 14.80 \\
\hline & \multicolumn{3}{|c|}{ Alcools } \\
\hline Methanol, g kg of DM ${ }^{-1}$ & $<0.50$ & $<0.50$ & 1.08 \\
\hline Ethanol, $\mathrm{g} \mathrm{kg}$ of $\mathrm{DM}^{-1}$ & 46.06 & 16.65 & 7.24 \\
\hline N-Propanol, g kg of DM-1 & 5.82 & 0.95 & 0.84 \\
\hline \multirow[t]{2}{*}{ N-Butanol, $\mathrm{g} \mathrm{kg}$ of $\mathrm{DM}^{-1}$} & $<0.50$ & $<0.50$ & $<0.50$ \\
\hline & \multicolumn{3}{|c|}{ Organic acids } \\
\hline Lactic acid $(L+D)$, g kg of $D^{-1}$ & 51.40 & 82.40 & 72.80 \\
\hline Acetic acid, $\mathrm{g} \mathrm{kg}$ of $\mathrm{DM}^{-1}$ & 49.18 & 27.90 & 46.98 \\
\hline Propionic acid, $\mathrm{g} \mathrm{kg}$ of $\mathrm{DM}^{-1}$ & 4.23 & 1.33 & 1.32 \\
\hline Iso-butyric acid, $\mathrm{g} \mathrm{kg}$ of $\mathrm{DM}^{-1}$ & $<0.50$ & 0.47 & $<0.50$ \\
\hline N-butyric acid, g kg of $\mathrm{DM}^{-1}$ & $<0.50$ & 0.76 & $<0.50$ \\
\hline Iso-valeric acid, $\mathrm{g} \mathrm{kg}$ of $\mathrm{DM}^{-1}$ & $<0.50$ & $<0.50$ & $<0.50$ \\
\hline $\mathrm{N}$-valeric acid, $\mathrm{g} \mathrm{kg}$ of $\mathrm{DM}^{-1}$ & $<0.50$ & $<0.50$ & $<0.50$ \\
\hline
\end{tabular}

$\mathrm{TS}=$ Triticale silage; $\mathrm{TSP}=$ Triticale silage with forage pea; TSOPV = Triticale silage with oats, vetch and forage pea; $\mathrm{N}=$ Nitrogen; $\mathrm{DM}=$ Dry matter.

According to Cherney and Cherney (2003), neutral products of fermentation such as ethanol and propanol may be present due to fermentation in the silo, but the acceptable concentration of ethanol should not exceed $50 \mathrm{~g} \mathrm{~kg}$ of $\mathrm{DM}^{-1}$ as this may be converted into acetate in the rumen. The values obtained in the present study were 16.65 and $7.24 \mathrm{~g} \mathrm{~kg}$ of $\mathrm{DM}^{-1}$ for TSOPV and TSP,

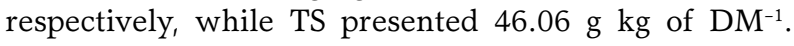
It is believed that the higher TS value may be due to secondary fermentation conducted primarily by yeasts.

Lactic acid production of TS was lower than others, maintaining a relationship with acetic acid close to $1: 1$. The higher concentration of $\mathrm{N}-\mathrm{NH}_{3}$ may have acted as a buffer in the medium and prevented more forceful action of the bacteria responsible for the production of this acid (Bumbieris Junior et al., 2010). Although lactic acid values were low, acetic acid production was satisfactory (McDonald et al., 1991) and sufficient to inhibit losses and provide good aerobic stability, as presented by Bumbieris Junior et al. (2010).

Dry matter intake, of silage and total, were significantly higher in the animals fed TSOPV and TSP $(p<0.01$; Table 3$)$. These results were verified, in the main, by the higher NDF content observed in triticale silage in monoculture assuming an anticipated physical limitation, reducing the potential for ingestion of the animals. Although a number of authors report a lower intake of silages with higher $\mathrm{N}-\mathrm{NH}_{3}$ levels and a higher concentration of acetic acid (Przemysław et al., 2015). This was not the case in our study.

The estimated water intake for cows with a level of production equivalent to that of the study varied from 55 to $65 \mathrm{~L} \mathrm{~d}^{-1}$ (Dahlborn et al., 1998). In addition to the water intake being within the aforementioned normal
Table 3 - Dry matter and water intake, yield and milk composition of Holstein cows fed with triticale silage in monoculture or intercropped with oats and / or legumes.

\begin{tabular}{|c|c|c|c|c|c|}
\hline & TS & TSP & TSOPV & SEM & $p$-value \\
\hline Silage intake, $\mathrm{kg} \mathrm{DM} \mathrm{d}^{-1}$ & $9.54^{b}$ & $11.48^{\mathrm{a}}$ & $12.25^{a}$ & 0.60 & $<0.01$ \\
\hline Total intake, $\mathrm{kg} \mathrm{DM} \mathrm{d}^{-1}$ & $14.90^{\mathrm{b}}$ & $16.84^{a}$ & $17.61^{\mathrm{a}}$ & 0.21 & $<0.01$ \\
\hline Total intake, $\%$ of live weight & $2.55^{b}$ & $2.91^{\mathrm{a}}$ & $3.01^{a}$ & 0.04 & $<0.01$ \\
\hline Average water intake, $L$ cow $d^{-1}$ & 59.10 & 59.80 & 60.23 & 0.72 & 0.79 \\
\hline $\begin{array}{l}\text { Ratio water intake: dry matter } \\
\text { intake }\end{array}$ & $3.93^{\mathrm{a}}$ & $3.56^{\mathrm{a}}$ & $3.88^{\mathrm{a}}$ & 0.07 & $<0.01$ \\
\hline Milk production, $\mathrm{kg} \mathrm{d}^{-1}$ & $18.74^{b}$ & $20.45^{\mathrm{ab}}$ & b $21.19^{a}$ & 0.38 & 0.02 \\
\hline $\begin{array}{l}\text { Feed efficiency, } \mathrm{kg} \text { of milk kg } \\
\text { of } \mathrm{DM}^{-1}\end{array}$ & 1. & 1.21 & 1.21 & 0.02 & 0 \\
\hline $\begin{array}{l}\text { Milk production at } 4 \% \text { of fat, } \\
\mathrm{kg} \mathrm{d}^{-1}\end{array}$ & 18.8 & 20.05 & $20.64^{a}$ & 0.40 & 0. \\
\hline Milk fat, $\mathrm{kg} \mathrm{d}^{-1}$ & 0.75 & 0.79 & 0.81 & 0.02 & 0.37 \\
\hline Milk protein, $\mathrm{kg} \mathrm{d}^{-1}$ & $0.53^{b}$ & $0.59^{a}$ & $0.63^{a}$ & 0.01 & $<0.01$ \\
\hline Milk fat, \% & 4.03 & 3.88 & 3.83 & 0.05 & 0.24 \\
\hline Milk protein, $\%$ & 2.86 & 2.92 & 2.96 & 0.02 & 0.20 \\
\hline Milk N-ureico, $\mathrm{mg} \mathrm{dL}^{-1}$ & $15.15^{b}$ & $19.05^{\mathrm{a}}$ & $19.58^{a}$ & 0.24 & $<0.01$ \\
\hline
\end{tabular}

Means followed by different letters in the line are statistically different by Tukey test at $5 \%$ significance; TS = Triticale silage; TSP = Triticale silage with forage pea; TSOPV = Triticale silage with oats, vetch and forage pea; DM = Dry matter; $d$ = Day; SEM = Standard error of mean.

range, it was not affected by the inclusion of legumes in triticale silage. According to Dahlborn et al. (1998), the ingestion of water is related to several factors, including dry matter intake. In this study, the relationship of water intake to dry matter intake was similar across treatments, and the values found are in agreement with the levels proposed by the NRC (2001).

The milk yield, in $\mathrm{kg} \mathrm{d}^{-1}$, was higher for cows fed TSOPV but did not differ from those receiving TSP (21.19 and $20.54 \mathrm{~kg} \mathrm{~d}^{-1}$, respectively), suggesting that higher intake of dry matter was associated with the higher nutritive value of these silages made possible by individual production. This difference disappeared when production was corrected to $4 \%$ fat, even though the percentages of fat and daily fat production themselves were not significantly affected.

The percentage of milk protein was similar across treatments, suggesting that legume intake did not increase the synthesis of microbial protein in the rumen. Although the percentage of milk protein was not different, daily protein production was higher $(p<0.01)$ for cows fed TSOPV and TSP $(0.63$ and 0.59 $\mathrm{kg} \mathrm{d}^{-1}$, respectively), accompanied by higher daily milk production of these animals. Similar results have been described by Dewhurst et al. (2009) for cows fed red clover and grasses.

As regards food efficiency, there was no difference between treatments, requiring a kilogram of total dry matter ingested for the production of $1.25,1.21$ and $1.21 \mathrm{~kg}$ of milk $\mathrm{d}^{-1}$ for the animals fed TS, TSP and TSOPV, respectively. Despite the lower production of milk by cows consuming TS, food efficiency remained at the same levels due to the lower intake of dry matter also observed in these animals. 
The cows fed TS had the lowest $\mathrm{N}$-ureic values in milk when compared to those fed TSP and TSOPV $(15.15$, 19.05 and $19.58 \mathrm{mg} \mathrm{dL}^{-1}$, respectively), which should be an implication of higher crude protein content in legume silages. According to Dickhoefer et al. (2018), diet imbalances between carbohydrates and protein, especially when counted as non-protein nitrogen, may result in low absorption of this nutrient, which tends to be eliminated, among other routes, through milk.

It is important that the concentration of rapidly available carbohydrates in the diet of cows fed legumes with high protein density is equivalent so that there is greater use of nonprotein nitrogen and less excretion through urine and feces. According to Silva et al. (2014), urinary nitrogen leads to environmental pollution, either by emissions of these gases into the air in the atmosphere or by leaching onto the surface and groundwater. However, nitrogen removal by feces contributes to soil fertilization (Chadwick et al., 2011; Dijkstra et al., 2013), which, together with the nitrogen fixation capacity of legumes, reduces costs and keeps the system more sustainable.

\section{Conclusions}

The inclusion of legumes in triticale provided better silage fermentation, a lower concentration of structural components and better digestibility of organic matter, producing a higher intake of dry matter and enhanced milk production by cows.

The crude protein content of silages increased according to the proportion of legumes present in the silage, and the concentration of $\mathrm{N}$-ureic in milk was higher in cows that consumed silage consorted with legumes.

\section{Authors' Contributions}

Conceptualization: Bumbieris Junior, V.H.; Emeli, J-C.; Jobim, C.C. Data acquisition: Bumbieris Junior, V.H.; Emeli, J-C. Novak, S. Data analysis: Bumbieris Junior, V.H.; Horst, E.H., Rossi, R.M. Design of methodology: Bumbieris Junior, V.H.; Emeli, J-C.; Jobim, C.C. Writing and editing: Bumbieris Junior, V.H.; Horst, E.H.; Novak, S.; Emeli, J-C.

\section{References}

Association of Official Analytical Chemists [AOAC]. 1997. Official Methods of Analysis. 16ed. Washington, DC, USA.

Aufrère, J. 1982. Prediction of forage digestibility by means of an enzymatic procedure. Annales de Zootechnie 31: 111-130 (in French, with abstract in English).

Boever, J.L.; Cottyn, B.G.; Brabander, D.L. 1999. Equations to predict digestibility and energy value of grass silages, maize silages, grass hays, compound feeds and raw materials for cattle. Nutrition Abstracts and Reviews. Series B: Livestock Feeds and Feeding 69: 835-850.
Brown, A.N.; Ferreira, G.; Teets, C.L.; Thomason, W.E.; Teutsch, C.D. 2018. Nutritional composition and in vitro digestibility of grass and legume winter (cover) crops. Journal of Dairy Science 101: 2037-2047.

Bumbieris Junior, V.H.; Jobim, C.C.; Emile, J-C.; Roman, J.; Silva, M.S.D. 2010. Aerobic stability of triticale silage in single culture or in mixtures with oat and/or legumes. Revista Brasileira de Zootecnia 39: 2349-2356.

Chadwick, D.; Sommer, S.; Thorman, R.; Fangueiro, D.; Cardenas, L.; Amon, B.; Misselbrook, T. 2011. Manure management. Implications for greenhouse gas emissions. Animal Feed Science Technology 166: 514-531.

Cherney, J.H.; Cherney, D.J.R. 2003. Assessing silage quality. p. 141-198. In: Buxton, D.R.; Muck, R.E.; Harrison, J.H, eds. Silage Science and Technology. American Society of Agronomy Madison, WI, USA.

Costa, P.M.; Villela, S.D.J.; Leonel, F.D.P.; Araújo, S.A.D.C.; Araújo, K.G.; Ruas, J.R.M.; Andrade, V.R. 2012. Intercropping of corn, brachiaria grass and leguminous plants: productivity, quality and composition of silages. Revista Brasileira de Zootecnia 41: 2144-2149.

Dahlborn, K.; Akerlind, M.; Gustafson, G. 1998. Water intake by dairy cows selected for high or low milk-fat percentage when fed two forage to concentrate ratios with hay or silage. Swedish Journal of Agricultural Research 28: 167-176.

Dewhurst, R.J.; Delaby L.; Moloney, A.; Boland, T.; Lewis, E. 2009. Nutritive value of forage legumes used for grazing and silage. Irish Journal of Agricultural and Food Research 48: 167187.

Dijkstra, J.; Oenema, O.; Van Groenigen, J.W.; Spek, J.W.; Van Vuuren, A.M.; Bannink, A. 2013. Diet effects on urine composition of cattle and $\mathrm{N}_{2} \mathrm{O}$ emissions. Animal 7: 292-302.

Dickhoefer, U.; Glowacki, S.; Gómez, C.A.; Castro-Montoya, J.M. 2018. Forage and protein use efficiency in dairy cows grazing a mixed grass-legume pasture and supplemented with different levels of protein and starch. Livestock Science 216: 109-118.

Emile, J-C.; Jobim, C.C.; Surault, F. 2007. Genetic variations in the digestibility in sheep of selected whole-crop cereals used as silages. Animal 1: 1122-1125.

Erwin, E.S.; Marco, G.J.; Emery, E.M. 1961. Volatile fatty acid analyses of blood and rumen fluid by gas chromatography. Journal of Dairy Science 44: 1768-1771.

Gierus, M.; Kleen, J.; Loges, R.; Taube, F. 2012. Forage legume species determine the nutritional quality of binary mixtures with perennial ryegrass in the first production year. Animal Feed Science and Technology 172: 150-161.

Godden, S.; Wilson, L.; Bey, R. 2003. Evaluation of the Azotest: strip as recommended for the estimation of milk urea nitrogen concentrations in individual cow, milk line and bulk tank samples. Bovine Practitioner 37: 36-43.

Heidelberger, P.; Welch, P. 1983. Simulation run length control in the presence of an initial transient. Operations Research 31: 1109-1144.

Lüscher, A.; Mueller Harvey, I.; Soussana, J.F.; Rees, R.M.; Peyraud, J.L. 2014. Potential of legume based grasslandlivestock systems in Europe: a review. Grass Forage Science 69: 206-228. 
McDonald, P.; Henderson, A.R.; Heron, S. 1991. The Biochemistry of Silage. 2ed. Marlow: Chalcombe Publications, UK.

McGoverin, C.M.; Snyders, F.; Muller, N.; Botes, W.; Fox, G.; Manley, M. 2011. A review of triticale uses and the effect of growth environment on grain quality. Journal of the Science of Food and Agriculture 91: 1155-1165.

National Research Council [NRC]. 2001. Nutrient Requirement of Dairy Cattle. NRC, Washington, DC, USA.

Przemysław, S.; Cezary, P.; Stanisław, M.; Krzysztof, L.; Barbara, P.; Zofia, A.; Ząbek, K. 2015. The effect of nutritional and fermentational characteristics of grass and legume silages on feed intake, growth performance and blood indices of lambs. Small Ruminant Research 123: 1-7.

Schmid, B.; Hector, A.; Saha, P.; Loreau, M. 2008. Biodiversity effects and transgressive overyielding. Journal of Plant Ecology 1: $95-102$
Silva, M.S.; Tremblay, G.F.; Bélanger, G.; Lajeunesse, J.; Papadopoulos, Y.A.; Fillmore, S.A.; Jobim, C.C. 2014. Forage energy to protein ratio of several legume-grass complex mixtures. Animal Feed Science and Technology 188: 17-27.

Van Soest, P.J.; Robertson, J.B.; Lewis, B.A. 1991. Methods for dietary fiber, neutral detergent fiber, and no starch polysaccharides in relation to animal nutrition. Journal of Dairy Science 74: 3583-3597.

Vatandoost, M.; Mesgaran, D.M.; Valizadeh, R. 2007. Effect of whole crop silages (Triticale or barley) versus corn silage on performance of Holstein lactating dairy cows. Journal of Animal and Veterinary Advances 6: 344-348. 